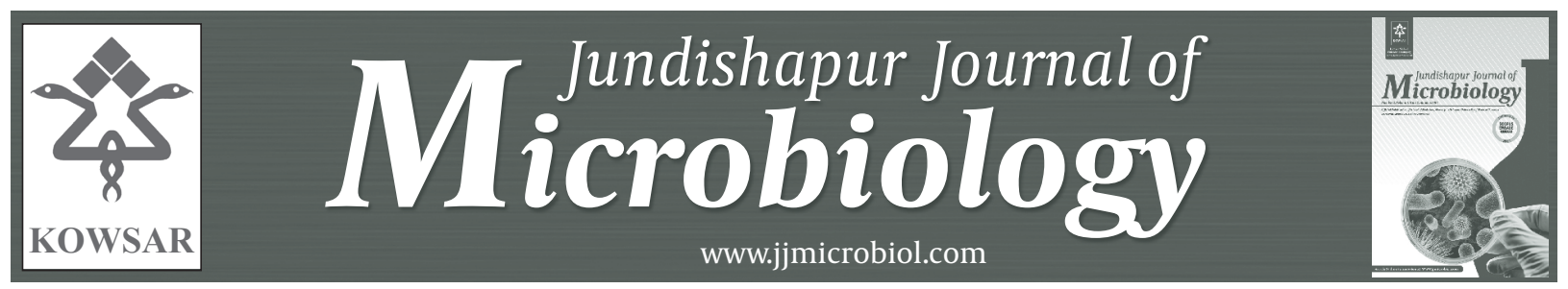

\title{
Genotype Analysis of Giardia lamblia Isolated From Children in Ahvaz, South- west of Iran
}

\author{
Elham Sadat Roointan ${ }^{1}$, Abdollah Rafiei ${ }^{2, *}$, Ali Reza Samarbaf-Zadeh ${ }^{3}$, Ali Akbar Shayesteh ${ }^{4}$, \\ Ahmad Shamsizadeh ${ }^{5}$, Mahdi Pourmahdi Borujeni ${ }^{6}$
}

${ }^{1}$ Parasitology Department, Faculty of Medicine, Ahvaz Jundishapur University of Medical Sciences, Ahvaz, IR Iran

${ }^{2}$ Parasitology Department, Faculty of Medicine, and Infectious and Tropical Diseases Research Center, Ahvaz Jundishapur University of Medical Sciences, Ahvaz, IR Iran

${ }^{3}$ Virology Department, Faculty of Medicine, Ahvaz Jundishapur University of Medical Sciences, Ahvaz, IR Iran

${ }^{4}$ Department of Internal Medicine, Imam Khomeini Hospital, Faculty of Medicine, Ahvaz Jundishapur University of Medical Sciences, Ahvaz, IR Iran

${ }^{5}$ Pediatreic Department and Infectious and Tropical Diseases Research Center, Ahvaz Jundishapur University of Medical Sciences, Ahvaz, IR Iran

${ }^{6}$ Department of Food Hygiene, Faculty of Veterinary Medicine, Shahid Chamran University of Ahvaz, Ahvaz, IR Iran

${ }^{*}$ Corresponding author Abdollah Rafiei, Parasitology Department, Faculty of Medicine, and Infectious and Tropical Diseases Research Center, Ahvaz Jundishapur University of Medical Sciences, Ahvaz, IR Iran.Tel:+ 98-6112230540, Fax:+ 98-6112231325, E-mail: rafieiabdollah@yahoo.com.

\begin{abstract}
A B S T R A C T
Background: Giardia lamblia is an enteric protozoan parasite, which infects human and a wide range of vertebrate hosts. Objectives: The aim of this study was to investigate genotypes of G. lamblia from children fecal samples in Ahvaz, South West of Iran by PCR-RFLP method.

Materials and Methods: Fecal samples were collected from 58 children who were positive for G. lamblia. DNA extractions were performed by QIAamp Stool Mini Kit. DNA were evaluated by semi nested PCR-RFLP assay, targeting the glutamate dehydrogenase (gdh) gene, which was used to distinguish within and between genotypes A and B.

Results: Fifty samples (86\%) were confirmed by semi-nested PCR. Genotype analysis among 50 isolates indicated 5 (10\%) and 8 (16\%) assemblages AII and B, respectively. Mixed Infections with both assemblages AII and B were also detected in 37 (74\%) cases.

Conclusions: Current study indicated the molecular characterization of G. lamblia in southwest of Iran. Postulated sources of contamination by accidental discharge of sewage effluent and faecal contamination from animals may contribute to this high rate of mixed infection in the current study. Further studies are needed to underestand the source and route of infection better.
\end{abstract}

Keywords: Giardia lamblia, Glutamate dehydrogenase (gdh), Semi nested PCR-RFLP, Ahvaz, Iran

Copyright ( $\odot$ 2013, Ahvaz Jundishapur University of Medical Sciences; Published by Kowsar Corp.

-Article type: Research Article; Received: 23 May 2012, Revised: 19 Jun 2012, Accepted: 01 Jul 2012; DOI: 10.5812/jjm.6443

-Implication for health policy/practice/research/medical education:

Results of current study indicated the genotypes of Giardia lamblia that would help us to understand the route of infection better.

PPlease cite this paper as:

Roointan ES, Rafiei A, Samarbaf-Zadeh AR, Shayesteh AA, Shamsizadeh A, Pourmahdi Borujeni M. Genotype Analysis of Giardia lamblia Isolated From Children in Ahvaz, Southwest of Iran. Jundishapur J Microbiol. 2013;6(3):279-83. DOI: 10.5812/jjm.6443

Copyright (C) 2013, Ahvaz Jundishapur University of Medical Sciences; Published by Kowsar Corp.

This is an Open Access article distributed under the terms of the Creative Commons Attribution License (http://creativecommons.org/licenses/by/3.0), which permits unrestricted use, distribution, and reproduction in any medium, provided the original work is properly cited. 


\section{Background}

Giardia lamblia is an intestinal parasite found in a wide range of mammals, including humans, and is considered as a zoonotic agent by the WHO $(1,2)$. It is one of the most frequent gastrointestinal pathogens in children that may cause malabsorption and weight loss (3). It has a global distribution in developed and developing countries, especially, in poor health conditions and over crowded papulations (4). The rates of infection among humans in different areas of the world vary from 5\% to $43 \%$ (4). Giardiainfection rates have been reported 5\% - 23\% in different parts of Iran and recently 9.1\% infection has been reported in rural areas of Khuzestan province, South west of $\operatorname{Iran}(5,6)$.

Based on molecular studies, a variety of genotyping techniques, including PCR-RFLP and sequence analysis of the gdh, tpi, efla and 18SrDNA gene have shown that G. lamblia is composed of a range of diverse genotypes A to $\mathrm{G}$ (7, 8). Assemblages A and B have been reported in humans and a broad range of other hosts, including livestock, cats, dogs, beavers and wild mammals (8-11). Assemblage A has been further grouped into subtypes I and II. The assemblage B has been classified into subtypes III and IV. Assemblages AII and BIV are considered to be specific for human (8-11). Assemblages C, D, E, F and G have been reported only in domestic animals, livestock and wild animals (10). PCR-RFLP is used as a sensitive, simple, and rapid method, and it has been successfully used by a number of researchers for Giardia genotyping (12-14). In addition, PCR-RFLP is advantageious for its ability to detect and identify the presence of mixed genotypesclearly. The gdh gene has been used successfully to genotype isolates of $G$. lamblia from mammals (13-15).

\section{Objectives}

The present study aimed to determine the genotypes of G. lamblia isolates from infected children cases in Ahvaz, southwest of Iran by a PCR-RFLP assay on the organism's glutamate dehydrogenase $(g d h)$ gene.

\section{Materials and Methods}

\subsection{Collection and Purification of Cysts}

Giardia-positive fecal samples were collected from children less than 15 years old who were referred to Ahvaz health centers clinics for medical examinations, during September 2011 to July 2012. Positive fecal samples were transferred to the Department of Parasitology, School of Medicine, Ahvaz University of Medical Sciences. The positive samples were confirmed by wet smear stained with
Lugol's iodine and formalin ether using light microscope at $400 \times$ magnification (16). Fifty eight positive fecal samples for G. lamblia cysts were used in the study. The intensity of infection was estimated by average cyst count per high power field (HPF) of light microscope. Samples` scores were divided into three categories: 1-5 (1+), 6-10 (2+) and more than 10 cysts (3+). All samples were stored as whole feces at $4^{\circ} \mathrm{C}$ without preservatives until used. Cysts were purified from the faeces by sucrose density gradient centrifugation and washed with sterile distilled water and then stored at $-20{ }^{\circ} \mathrm{C}$ until used (17).

\subsection{DNA Extraction}

G. lamblia cysts were 10 times freez-thawed on $-80^{\circ} \mathrm{C} /+80^{\circ} \mathrm{C}$. Subsequentely, DNA was extracted from 200 $\mu \mathrm{l}$ of purified samples by the QIAamp DNA Stool Mini Kit (Qiagen, Germany) according to the instructions of the manufacturer. DNA samples were stored at $-20^{\circ} \mathrm{C}$ until used.

\subsection{PCR Amplification}

The amplification of the gdh gene was performed by a semi-nested PCR protocol. In the semi- nested PCR reaction, a fragment of approximately 432 base pairs of the gdh gene were amplified with external forward primer GDHeF (TCA ACG TYA AYC GYG GYT TCC GT), internal forward primer GDHiF (CAG TAC ACC TCY GCT CTC GG), and reverse primer GDHiR (GTT RTC CTT GCA CAT CTC C; (15). The primers were tested with positive control. The positive control for G. lamblia was received from a colleague in Kerman University of Medical Sciences. Distilled water was used as negative control.

The PCR reaction mixture consisted of $5 \mu$ l genomic DNA, $5 \mu \mathrm{l}$ of $10 \mathrm{X}$ buffer (Fermentas, Lithuania), $1.5 \mu \mathrm{l}$ (50mM) MgCl2,1 $\mu \mathrm{l}(10 \mathrm{mM}) \mathrm{dNTP}$ mix , $0.3 \mu \mathrm{l}(5 \mathrm{U} / \mu \mathrm{l})$ Taq DNA polymerase, and $1 \mu \mathrm{l}$ (12.5 pmol) of each primer. The reactions were carried out in $50 \mu \mathrm{l}$ volumes. GDHeF and GDHiR were used in the primary PCR reaction. One microliter of the PCR primary reaction product was added to the secondary PCR containing primers GDHiF and GDHiR. PCR was carried out on a thermocycler (iCycler, BioRad) with the following amplification condition: 1 cycle of $94{ }^{\circ} \mathrm{C}$ for $3 \mathrm{~min}, 56^{\circ} \mathrm{C}$ for $1 \mathrm{~min}$ and $72^{\circ} \mathrm{C}$ for $2 \mathrm{~min}$, followed by 35 cycles, $94^{\circ} \mathrm{C}$ for $1 \mathrm{~min}, 56^{\circ} \mathrm{C}$ for $20 \mathrm{~s}$ and $72^{\circ} \mathrm{C}$ for $45 \mathrm{~s}$. A final extension of $72{ }^{\circ} \mathrm{C}$ for $7 \mathrm{~min}$ and a $20^{\circ} \mathrm{C}$ hold was used (15). The PCR products were electrophoresed on ethidium bromide stained $1 \%$ agarose gels (Roche, Germany).

\subsection{PCR-RFLP of Region of gdh Gene}

RFLP analysis was carried out by digesting $10 \mu \mathrm{l}$ of PCR product. It was added to $1 \mathrm{X}$ enzyme buffer, and $2 \mu \mathrm{l}(10$ $\mathrm{U} / \mu \mathrm{l})$ BspL1 (NIaIV) enzyme (Fermentas, Lithuania) or $2 \mu \mathrm{l}$ $(10 \mathrm{U} / \mu \mathrm{l})$ Rsalenzyme (Roche, Germany) for $16 \mathrm{~h}$ at $37^{\circ} \mathrm{C}$. The final volumes of Rsa1 and BspL1 enzymes were 25 and 
$30 \mu \mathrm{l}$, respectively. The BspL1 enzyme digestion was used to distinguish between groups I and II of assemblages A and assemblages B. Rsa1 enzyme digestion distinguished between subtypes BIII and BIV (15). Restriction fragments were separated in $3 \%$ high resolution grade agarose (Roche, Germany) stained with ethidium bromide. A 50bp DNA ladder (Fermentas, Lithuania) was used as size marker.

\section{Results}

The $g d h$ gene was successfully amplified from 50 samples. A $432 \mathrm{bp}$ fragment of gdh gene was amplified in the PCR using primers GDHiF and GDHiR ( Figure 1). PCR products of these samples were digested with BspL1 and Rsa1enzymes.

\section{Figure 1. PCR Products on An Ethidium Bromide-Stained 1\% Agarose Gel}

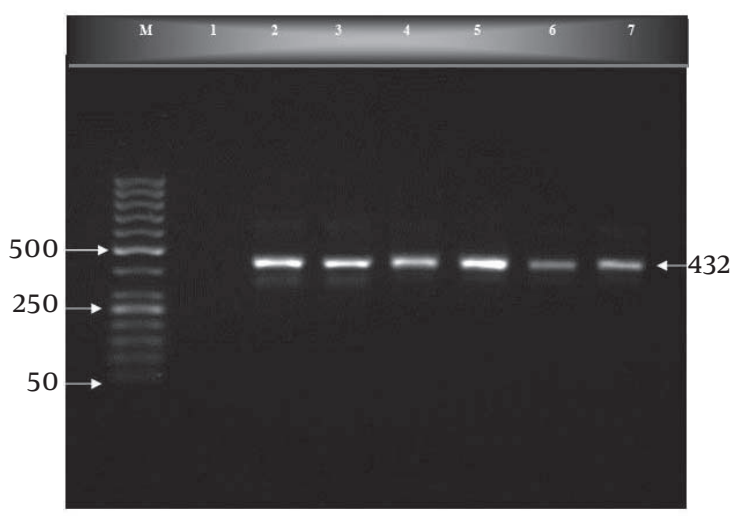

lane M, molecular weight marker (50 bp); lane 1, negative control; lane 2, positive control; lanes 3-7, PCR products from clinical samples.

The predicted restriction fragment sizes are provided in Table 1 . Thirty seven (74\%) cases generated six bands of $40,70,80,90,120$ and $290 \mathrm{bp}$, which indicated mixed genotypes AII and B. Eight (16\%) samples generated two bands of 130 and 300 bp indicating assemblages BIII. Five (10\%) samples revealed four bands of 70, 80, 90 and 120 bp, indicating assemblage AII ( Figure 2 and Table 2 ). Assemblages AI and BIV were not detected in the study.

Table 1. Predicted Fragment Sizes (bp) of G. lamblia Assemblages After Digesting With BspL1 and Rsa1 Enzyme

\begin{tabular}{llll}
\hline $\begin{array}{l}\text { Assem- } \\
\text { blage }\end{array}$ & Enzyme & $\begin{array}{l}\text { Predicted frag- } \\
\text { ment Sizes }\end{array}$ & $\begin{array}{l}\text { Diagnostic genotyp- } \\
\text { ing profile }\end{array}$ \\
\hline AI & BspL1 & $\begin{array}{l}16,18,39,87,123, \\
149\end{array}$ & $90,120,150$ \\
\hline AII & BspL1 & $\begin{array}{l}16,18,39,72,77, \\
87,123\end{array}$ & $40,70,80,90,120$ \\
\hline B & BspL1 & 18,123291 & 120,290 \\
BIIl & Rsa1 & $2,133,297$ & 130,300 \\
\hline BIV & Rsa1 & $\mathrm{I} 2,430$ & 430 \\
\hline
\end{tabular}

Figure 2. Enzyme Digestion of gdh- PCR Products of G. lamblia on An Ethidium Bromide-Stained 3\% High Resolution Grade Agarose Gel.

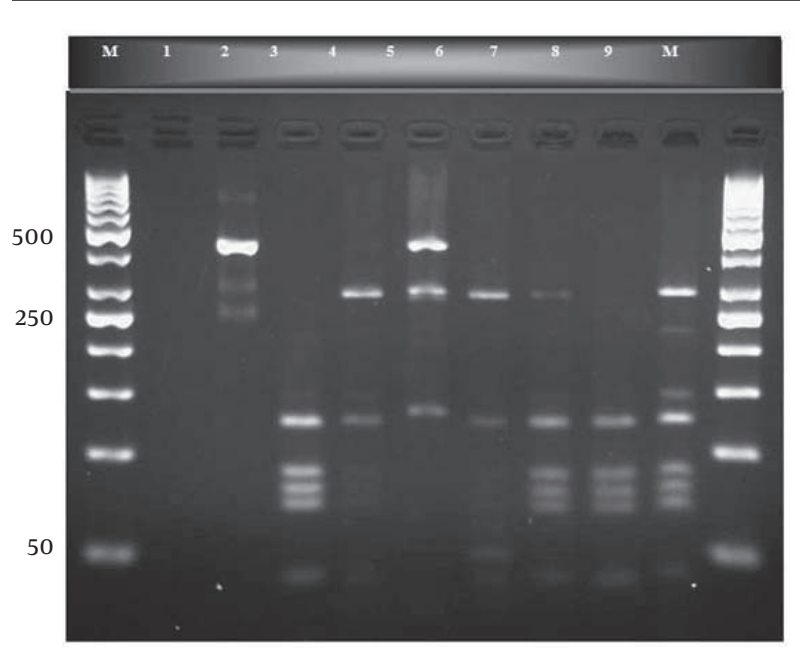

Lane M, molecular weight marker (50 bp). Lane 1, negative control. Lane 2 PCR product (432 bp fragment). Lane 3, Bspl1 enzyme digestion of G. lamblia standard strain (genotype AII). Lanes 4,6,7,9 mixed genotype AII and B. Lane 5, Assemblage B group BIII (Rsa1 enzyme digestion) and Lane 8, assemblage AII ( Bspl1 enzyme digestion).

\section{Discussion}

G. lamblia , distributed globally, is the most common intestinal parasite of humans in the developed and developing countries $(4,18)$. This protozoa is recently included in the 'Neglected Diseases Initiative' by the WHO (19). The routine diagnostic method for giardiasis is the microscopic detection of Giardia cysts in stools. Molecular analyses such as PCR provided alternative methods to diagnose $G$. lamblia with greater sensitivity than microscopic examination (20-22). The present study indicated that $86 \%$ (50/58) microscopic positive samples were identified by seminested PCR. Eigth (14\%) samples with low numbers of cysts were negative after seminested PCR. Bertrand et al. (23) reported 19.3\% false negative result when the $g d h$ gene was amplified by nested PCR. In a study conducted by Amar et al. (12) the tpi gene was amplified by semi-nested PCR and the study indicated 6\% false negative results. Although there is no clear explanation for such false negative results, it could be due to low DNA level, or existence of a robust wall that inhibits release of DNA from the cystes.

the current study results indicated a mixture of assemblages AII and B in 74\% (37/50) of samples. Assemblages B and $A$ were detected in 16\% (8/50) and 10\% (5/50), respectivly. A few studies are done in Iran on G. lamblia genotypes, Babaei etal. (24) reported $87 \%$ assemblages AII and $8.7 \%$ assemblage B in Tehran. Another study in Kerman, South east of Iran indicated simillar frequency results in- 
cluding $60 \%$ assemblage AII, $23.4 \%$ assemblage B and $16.6 \%$ assemblage $\mathrm{AI}$ (25). reported by Etemadi et al. (25) and Hatam-Nahavandi et al. (26) where not detected in the current study.

Table 2. All Data About Laboratory Outcomes and Assemblages of G. lamblia Isolates Examined by RFLP Analysis at the gdh Gene in Children Cases

\begin{tabular}{|c|c|c|c|c|c|}
\hline Case No. & Stool Microscopy & Gdh RFLP & Case No. & Stool Microscopy & Gdh RFLP \\
\hline $\mathbf{1}$ & Cyst & $\mathrm{AII}+\mathrm{B}$ & 26 & Cyst+Trophozoite & $\mathrm{AII}+\mathrm{B}$ \\
\hline 2 & Cyst & AII $+\mathrm{B}$ & 27 & Cyst & AII+B \\
\hline 3 & Cyst & AII $+\mathrm{B}$ & 28 & Cyst & AII + B \\
\hline 4 & Cyst & B & 29 & Cyst & AII+B \\
\hline 5 & Cyst & AII $+\mathrm{B}$ & 30 & Cyst & AII+B \\
\hline 6 & Cyst & AII+B & 31 & Cyst & $\mathrm{AII}+\mathrm{B}$ \\
\hline 7 & Cyst & AII $+\mathrm{B}$ & 32 & Cyst & $\mathrm{AII}+\mathrm{B}$ \\
\hline 8 & Cyst & AII+B & 33 & Cyst+Trophozoite & AII+B \\
\hline 9 & Cyst & AII+B & 34 & Cyst & AII \\
\hline 10 & Cyst & $\mathrm{AII}+\mathrm{B}$ & 35 & Cyst+Trophozoite & B \\
\hline 11 & Cyst & AII & 36 & Cyst & B \\
\hline 12 & Cyst & $\mathrm{AII}+\mathrm{B}$ & 37 & Cyst & B \\
\hline 13 & Cyst & $\mathrm{AII}+\mathrm{B}$ & 38 & Cyst & AII \\
\hline 14 & Cyst & AII+B & 39 & Cyst & B \\
\hline 15 & Cyst & $\mathrm{AII}+\mathrm{B}$ & 40 & Cyst & AII \\
\hline 16 & Cyst+Trophozoite & $\mathrm{AII}+\mathrm{B}$ & 41 & Cyst & $\mathrm{AII}+\mathrm{B}$ \\
\hline 17 & Cyst & AII $+\mathrm{B}$ & 42 & Cyst & AII+B \\
\hline 18 & Cyst & B & 43 & Cyst+Trophozoite & $\mathrm{AII}+\mathrm{B}$ \\
\hline 19 & Cyst & $\mathrm{AII}+\mathrm{B}$ & 44 & Cyst & AII $+\mathrm{B}$ \\
\hline 20 & Cyst & $\mathrm{AII}+\mathrm{B}$ & 45 & Cyst & AII \\
\hline 21 & Cyst & B & 46 & Cyst & AII+B \\
\hline 22 & Cyst & AII+B & 47 & Cyst & AII \\
\hline 23 & Cyst & $\mathrm{AII}+\mathrm{B}$ & 48 & Cyst & B \\
\hline 24 & Cyst & $\mathrm{AII}+\mathrm{B}$ & 49 & Cyst & AII+B \\
\hline 25 & Cyst & $\mathrm{AII}+\mathrm{B}$ & 50 & Cyst & AII+B \\
\hline
\end{tabular}

Results of a study conducted in the North west of Iran, indicated $66.7 \%$ assemblage B and $33.3 \%$ AII (26). Most of researches from different parts of the world have reported the assemblages A and B as the most prevelant G. lamblia genotypes in human infection.

In Egypt Helmy et al. (27) found 58.5\% AI, 17.1\% AII and 19.5\% genotypes B among 41 patients. In Saudi Arabia, Hamdan (28) reported that in 40 gastrointestinal symptomatic and asymptomatic Saudi children $57.5 \%$ were assemblages A and $37.5 \%$ were assemblage B. On the other hand, results of a study conducted by Singh et al. (29) in Nepal indicated that assemblage B $(74 \%)$ was more prevalent than assemblage A (20\%). In Brazil, Kohli et al. (30) reported $74.1 \%$ and $5 \%$ assemblages $B$ and A , respectively among 47 children. Regarding types of assemblages, results of the current research is in agreement with Babaei et al. (24). In contrast, assemblages AI and BIV which were
According to the current study literature review, it seems that the rate of mixed infection with genotypes AII and B in the current study report is higher than those of others $(1,29,31-33)$. In addition, mixed infection which was predominant in South west of Iran, was only reported by Babaei et al. (24) with the lowest prevalence in their report. It has been also reported that these differences in the prevalence of assemblages may be attributed to the geographical location, but this finding could indicate a potential risk of waste exposuer to the source of drinking water, and in addition the life style of the studied population who may be in close contact with animal wastes, specially in rural areas.

In conclusion, this multiple infection may reflect ingestion of contaminated sources by human and animals wastes. Furthermore patients may be repeatedly and cumulatively exposed to the parasite due to poor sanitation in the 
studied area. Finally it seems that significance of the predominant mixed infection in the current study is unclear and further studies with a variety of enviromental samples are needed in order to examine, and figure out the dynamics and transmission route of Girardia better.

\section{Acknowledgements}

The authors wish to thank the health centers staffs and all patients who participated in the survey undertaken.

\section{Financial Disclosure}

All authors declare that they have no conflict of interest.

\section{Funding/Support}

The study was financially supported by Ahvaz Jundishapur University of Medical Sciences, Ahvaz, Iran, as part of PhD thesis of Miss Elham Roointan.

\section{Authors' Contribution}

None declared.

\section{References}

1. Adam Rodney D. Biology of Giardia lamblia. Clin Microbiol Rev. 2001;14(3):447-475

2. World Health Organization. Expert Committee on Parasitic Zoonoses . Parasitic Zoonoses: Report of a WHO Expert Committee with the Participation of FAO. 1979.

3. Thompson RC, Monis PT. Variation in Giardia: implications for taxonomy and epidemiology. Adv Parasitol. 2004;58:69-137

4. Topley, Wilson, Despommier DD. Parasitology. In: Wakelin D, Gillespie SH, Microbiology and Microbial Infection. 2005.

5. Mowlavi GR, MirAhmadi H, Rezaeian M, Kia E, Rokni MB, Goles$\tan B$, et al. Prevalence of intestinal parasites in tribal parts of Khuzestan Province during 2005-07. Govaresh. 2012;12(4):219-228

6. Taherkhani H, Shariati S, Abdolahi N, Roshandel GH. Clinical manifestations of Giardiasis in Iran.J Clin Diagn Res. 2009;3:14161418

7. Monis PT, Andrews RH, Mayrhofer G, Ey PL. Molecular systematics of the parasitic protozoan Giardia intestinalis. Mol Biol Evol. 1999;16(9):1135-44

8. Thompson RC. Giardiasis as a re-emerging infectious disease and its zoonotic potential. Int J Parasitol. 2000;30(12-13):1259-67

9. Hunter PR, Thompson RC. The zoonotic transmission of Giardia and Cryptosporidium. Int J Parasitol. 2005;35(11-12):1181-90

10. Monis PT, Thompson RC. Cryptosporidium and Giardia-zoonoses: fact or fiction? Infect Genet Evol. 2003;3(4):233-44

11. Thompson RC. The zoonotic significance and molecular epidemiology of Giardia and giardiasis. Vet Parasitol. 2004;126(1-2):1535

12. Amar CF, Dear PH, Pedraza-Diaz S, Looker N, Linnane E, McLauchlin J. Sensitive PCR-restriction fragment length polymorphism assay for detection and genotyping of Giardia duodenalis in human feces. J Clin Microbiol. 2002;40(2):446-52

13. Homan WL, Gilsing M, Bentala H, Limper L, van Knapen F. Characterization of Giardia duodenalis by polymerase-chain-reaction fingerprinting. Parasitol Res. 1998;84(9):707-14
14. Monis PT, Mayrhofer G, Andrews RH, Homan WL, Limper L, Ey PL. Molecular genetic analysis of Giardia intestinalis isolates at the glutamate dehydrogenase locus. Parasitology. 1996;112 ( Pt 1):1-12

15. Read CM, Monis PT, Thompson RC. Discrimination of all genotypes of Giardia duodenalis at the glutamate dehydrogenase locus using PCR-RFLP. Infect Genet Evol. 2004;4(2):125-30

16. Garcia LS, Bruckner DA. Diagnostic medical parasitology. 1997.

17. Barazesh A, Majidi J, Fallah E, Jamali R, Ghazanchaii A. Comparison of three different methods for concentration and purification of Giardia cyst. J Yafte. 2006;8(3):71-76

18. Lane S, Lloyd D. Current trends in research into the waterborne parasite Giardia. Crit Rev Microbiol. 2002;28(2):123-47

19. Savioli L, Smith H, Thompson A. Giardia and Cryptosporidium join the 'Neglected Diseases Initiative'. Trends Parasitol. 2006;22(5):203-8

20. Caccio SM, De Giacomo M, Pozio E. Sequence analysis of the betagiardin gene and development of a polymerase chain reactionrestriction fragment length polymorphism assay to genotype Giardia duodenalis cysts from human faecal samples. Int J Parasitol. 2002;32(8):1023-30

21. McGlade TR, Robertson ID, Elliot AD, Thompson RC. High prevalence of Giardia detected in cats by PCR. Vet Parasitol. 2003;110(34):197-205

22. Miller KM, Sterling CR. Sensitivity of nested PCR in the detection of low numbers of Giardia lamblia cysts. Appl Environ Microbiol. 2007;73(18):5949-50

23. Bertrand I, Albertini L, Schwartzbrod J. Comparison of two target genes for detection and genotyping of Giardia lamblia in human feces by PCR and PCR-restriction fragment length polymorphism. JClin Microbiol. 2005;43(12):5940-4

24. Babaei Z, Oormazdi H, Akhlaghi L, Rezaie S, Razmjou E, SoltaniArabshahi SK, et al. Molecular characterization of the Iranian isolates of Giardia lamblia: application of the glutamate dehydrogenase gene. Iran J Pub Health. 2008;37(2)

25. Etemadi S, Zia-Ali N, Babaei Z. The Correlation between Clinical Signs and Genotypes of Giardia duodenalis Isolated from Patients with Giardiasis in Kerman City. J Kerman Univ Med Sci. 2011;18(4):330-8

26. Hatam Nahavandı K, Fallah E, Asgharzadeh M, Mırsamadı N, Mahdavipour B. Glutamate dehydrogenase and triose-phosphate-isomerase coding genes for detection and genetic characterization of Giardia lamblia in human feces by PCR and PCRRFLP. TurkJ Med Sci. 2011;41(2):283-289

27. Helmy MM, Abdel-Fattah HS, Rashed L. Real-time PCR/RFLP assay to detect Giardia intestinalis genotypes in human isolates with diarrhea in Egypt.J Parasitol. 2009;95(4):1000-4

28. Al-Mohammed HI. Genotypes of Giardia intestinalis clinical isolates of gastrointestinal symptomatic and asymptomatic Saudi children. Parasitol Res. 2011;108(6):1375-81

29. Singh A, Janaki L, Petri WA, Jr, Houpt ER. Giardia intestinalis assemblages A and B infections in Nepal. Am J Trop Med Hyg. 2009;81(3):538-9

30. Kohli A, Bushen OY, Pinkerton RC, Houpt E, Newman RD, Sears CL, et al. Giardia duodenalis assemblage, clinical presentation and markers of intestinal inflammation in Brazilian children. Trans $R$ Soc Trop Med Hyg. 2008;102(7):718-25

31. Guy RA, Xiao C, Horgen PA. Real-time PCR assay for detection and genotype differentiation of Giardia lamblia in stool specimens. J Clin Microbiol. 2004;42(7):3317-20

32. Tungtrongchitr A, Sookrung N, Indrawattana N, Kwangsi S, Ongrotchanakun J, Chaicumpa W. Giardia intestinalis in Thailand: identification of genotypes. J Health Popul Nutr. 2010;28(1):42-52

33. Yason JA, Rivera WL. Genotyping of Giardia duodenalis isolates among residents of slum area in Manila, Philippines. Parasitol Res. 2007;101(3):681-7 